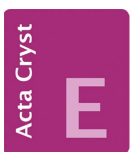

CRYSTALLOGRAPHIC COMMUNICATIONS

ISSN 2056-9890

Received 20 May 2020

Accepted 20 May 2020

Edited by W. T. A. Harrison, University of Aberdeen, Scotland

Keywords: crystal structure; thiourea; hydrogen bonding; Hirshfeld surface analysis; computational chemistry.

CCDC reference: 2004940

Supporting information: this article has supporting information at journals.iucr.org/e

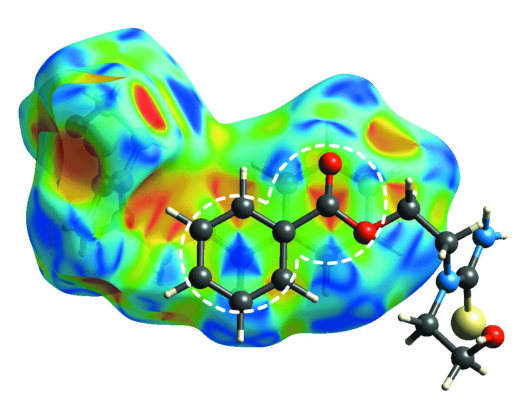

OPEN $\odot$ ACCESS

\section{2-[Carbamothioyl(2-hydroxyethyl)amino]ethyl benzoate: crystal structure, Hirshfeld surface analysis and computational study}

\author{
Sang Loon Tan and Edward R. T. Tiekink*
}

Research Centre for Crystalline Materials, School of Science and Technology, Sunway University, 47500 Bandar Sunway, Selangor Darul Ehsan, Malaysia. *Correspondence e-mail: edwardt@sunway.edu.my

The title di-substituted thiourea, $\mathrm{C}_{12} \mathrm{H}_{16} \mathrm{~N}_{2} \mathrm{O}_{3} \mathrm{~S}$, has the hydroxylethyl and ethyl benzoate substituents bound to the same amine- $\mathrm{N}$ atom, and is twisted, having a (+)syn-clinal conformation with the $\mathrm{N}_{\text {amine }}-\mathrm{C}-\mathrm{C}-\mathrm{O}_{\text {(hydroxyl, carbonyl) }}$ torsion angles of 49.39 (13) and $59.09(12)^{\circ}$, respectively; the dihedral angle between the almost planar $\mathrm{CN}_{2} \mathrm{~S}$ core and the pendent benzene ring is 69.26 (4) ${ }^{\circ}$. In the crystal, supramolecular layers propagating in the $a c$ plane are formed via a combination of hydroxyl-O-H $\cdots \mathrm{S}$ (thione), amine- $\mathrm{N}-\mathrm{H} \cdots \mathrm{O}$ (hydroxyl, carbonyl) hydrogen-bonds. The layers stack along the $b$ axis with inter-digitation of the benzene rings allowing the formation of $\pi-\pi$ stacking [inter-centroid separation $=3.8722(7) \AA]$ and parallel $\mathrm{C}=\mathrm{O} \cdots \pi$ interactions. A computational chemistry study shows the conventional hydrogen bonding in the crystal leads to significant electrostatic stabilization but dispersion terms are also apparent, notably through the interactions involving the benzene residue.

\section{Chemical context}

The title compound, (I), was characterized crystallographically in a continuation of recent structural studies of tri-substituted thiourea derivatives formulated as $\left(\mathrm{HOCH}_{2} \mathrm{CH}_{2}\right)_{2} \mathrm{NC}(=\mathrm{S})$ $\mathrm{N}(\mathrm{H}) \mathrm{C}(=\mathrm{O}) \mathrm{C}_{6} \mathrm{H}_{4}-R-4$ for $R=\mathrm{Me}$ (Tan, Azizan et al., 2019) and $R=\mathrm{NO}_{2}$ (Tan et al., 2020): these molecules are known for their various applications including biological activity (Saeed et al., 2014). A convenient synthesis for these molecules is via the reaction of $\mathrm{NH}_{4}(\mathrm{NCS}), R_{2} \mathrm{NH}$ and $A r C(=\mathrm{O}) \mathrm{Cl}$ to yield $R_{2} \mathrm{NC}(=\mathrm{S}) \mathrm{N}(\mathrm{H}) \mathrm{C}(=\mathrm{O}) A r$. In an experiment with $R=$ $\mathrm{CH}_{2} \mathrm{CH}_{2} \mathrm{OH}$ and $\mathrm{Ar}=\mathrm{C}_{6} \mathrm{H}_{5}$, the solution was also heated resulting in an apparent rearrangement with deprotonation of one hydroxyethyl group followed by nucleophilic attachment at the carbonyl- $\mathrm{C}$ atom along with protonation of the primary amine and cleavage of the original $\mathrm{N}-\mathrm{C}(=\mathrm{O})$ bond to yield (I), formulated as $\mathrm{H}_{2} \mathrm{NC}(=\mathrm{S}) \mathrm{N}\left(\mathrm{CH}_{2} \mathrm{CH}_{2} \mathrm{OH}\right) \mathrm{CH}_{2} \mathrm{CH}_{2} \mathrm{O}$ $\mathrm{C}(=\mathrm{O}) \mathrm{C}_{6} \mathrm{H}_{5}$. The molecular structure of (I) was determined by X-ray crystallography and the supramolecular association investigated by Hirshfeld surface analysis and computational chemistry.<smiles>NC(=S)N(CCO)CCOC(=O)c1ccccc1</smiles> 


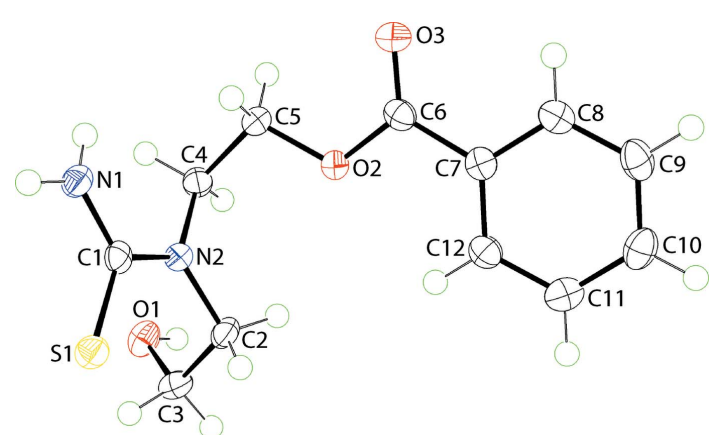

Figure 1

The molecular structure of (I) showing the atom-labelling scheme and displacement ellipsoids at the $70 \%$ probability level.

\section{Structural commentary}

The molecule of (I) is shown in Fig. 1 and comprises a disubstituted thiourea molecule with both substitutions occurring at the same amine atom. The $\mathrm{CN}_{2} \mathrm{~S}$ atoms of the thiourea core are almost planar, exhibiting a r.m.s. deviation = $0.0054 \AA$, with the appended $\mathrm{C} 2$ and $\mathrm{C} 4$ atoms lying 0.0236 (18) and 0.0216 (16) $\AA$ to either side of the plane. The conformation of the C2-hydroxylethyl residue is $(+)$ syn-clinal as indicated by the $\mathrm{N} 2-\mathrm{C} 2-\mathrm{C} 3-\mathrm{O} 1$ torsion angle of $49.39(13)^{\circ}$. The $\mathrm{CO}_{2}$ residue is close to co-planar with the (C7-C12)-benzene ring to which it is connected, forming a
Table 1

Hydrogen-bond geometry $\left(\AA{ }^{\circ}\right)$.

$C g 1$ is the centroid of the (C7-C12) ring.

\begin{tabular}{lllll}
\hline$D-\mathrm{H} \cdots A$ & $D-\mathrm{H}$ & $\mathrm{H} \cdots A$ & $D \cdots A$ & $D-\mathrm{H} \cdots A$ \\
\hline $\mathrm{O} 1-\mathrm{H} 1 O \cdots \mathrm{S}^{\mathrm{i}}$ & $0.84(1)$ & $2.35(1)$ & $3.1746(9)$ & $169(2)$ \\
$\mathrm{N} 1-\mathrm{H} 2 N \cdots{ }^{\mathrm{ii}}$ & $0.88(1)$ & $2.04(1)$ & $2.8582(13)$ & $155(1)$ \\
$\mathrm{N} 1-\mathrm{H} 1 N \cdots \mathrm{O} 3^{\mathrm{iii}}$ & $0.88(1)$ & $2.30(1)$ & $3.1218(13)$ & $158(1)$ \\
$\mathrm{C} 6-\mathrm{O} 3 \cdots C g 1^{\text {iv }}$ & $1.21(1)$ & $3.66(1)$ & $3.5026(12)$ & $73(1)$ \\
\hline
\end{tabular}

Symmetry codes: (i) $x+1, y, z$; (ii) $-x+1,-y,-z+2$; (iii) $-x+1,-y,-z+1$; (iv) $-x+1,-y+1,-z+1$.

dihedral angle of $4.83(9)^{\circ}$. The dihedral angle between the least-squares planes through the $\mathrm{CN}_{2} \mathrm{~S}$ core and the benzene ring is $69.26(4)^{\circ}$, indicating the molecule is highly twisted. Finally, the $\mathrm{N} 2-\mathrm{C} 4-\mathrm{C} 5-\mathrm{O} 2$ torsion angle of $59.09(12)^{\circ}$ is indicative of a $(+)$ syn-clinal configuration about the $\mathrm{C}-\mathrm{C}$ bond, thereby confirming the twisted nature of the molecule.

\section{Supramolecular features}

As anticipated, hydrogen bonding plays a key role in the supramolecular assembly of (I); see Table 1 for geometrical

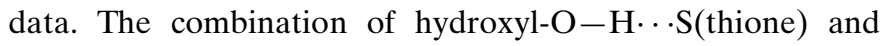
amine- $\mathrm{N}-\mathrm{H} \cdots \mathrm{O}$ (hydroxyl) hydrogen bonds connect molecules into a supramolecular tape propagating along the $a$-axis direction, Fig. 2(a). These hydrogen bonds also lead to the

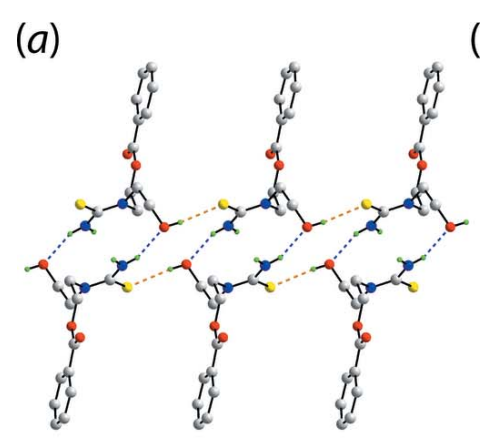

(b)

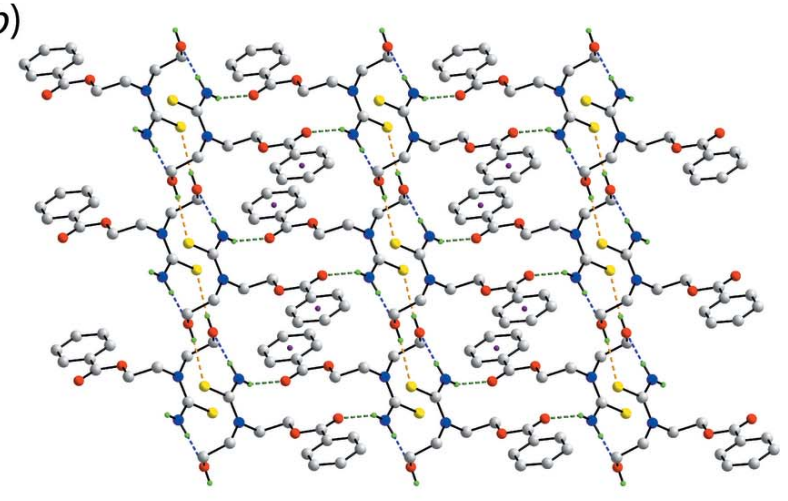

(c)

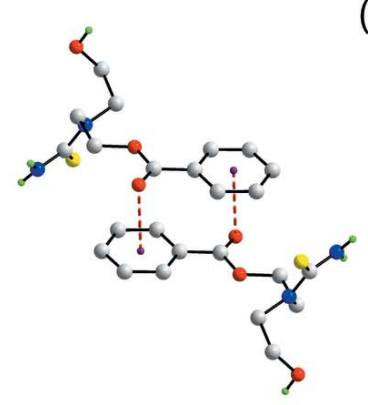

(d)

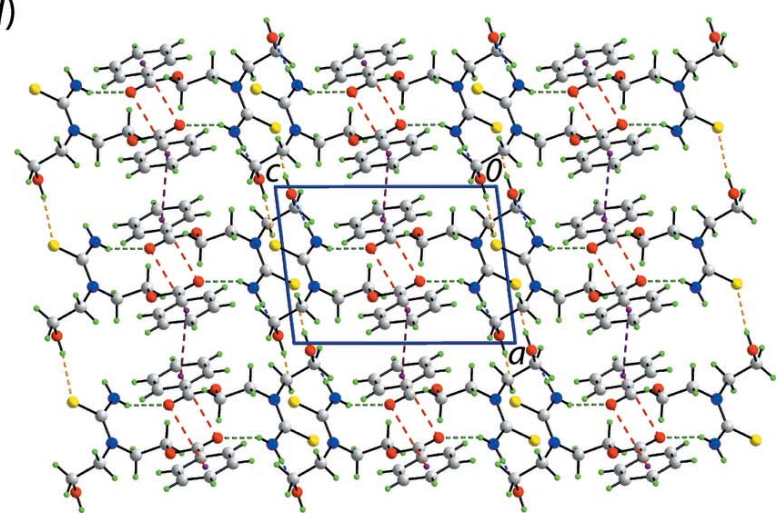

Figure 2

Molecular packing in the crystal of (I): (a) supramolecular tape along the $a$ axis mediated by hydroxyl-O $-\mathrm{H} \cdots \mathrm{S}($ thione) and amine-N$\mathrm{H}$... O (hydroxyl) hydrogen bonding shown as orange and blue dashed lines, respectively, $(b)$ supramolecular layer where the tapes of $(a)$ are connected by amine- $\mathrm{N}-\mathrm{H} \cdots \mathrm{O}$ (carbonyl) hydrogen bonds shown as green dashed lines, $(c)$ detail of $\mathrm{C}-\mathrm{O} \cdots \pi($ benzene) interactions shown as red dashed lines and $(d)$ a view of the unit-cell contents down the $b$ axis with $\pi$ (benzene) $-\pi$ (benzene) interactions shown as purple dashed lines. 
Table 2

A summary of short interatomic contacts $(\AA)$ for $(\mathrm{I})^{a}$.

\begin{tabular}{lllll}
\hline Contact & Distance & $\Sigma \mathrm{vdW}$ & $\Delta\left|\left(d_{\text {norm }}-\Sigma \mathrm{vdW}\right)\right|$ & Symmetry operation \\
\hline $\mathrm{H} 2 N \cdots \mathrm{O} 1^{b}$ & 1.92 & 2.61 & 0.69 & $1-x,-y, 2-z$ \\
$\mathrm{H} O \cdots \mathrm{S}^{b}$ & 2.21 & 2.89 & 0.68 & $1+x, y, z$ \\
$\mathrm{H} 1 N \cdots \mathrm{O} 3^{b}$ & 2.17 & 2.61 & 0.44 & $1-x,-y, 1-z$ \\
$\mathrm{H} 3 B \cdots \mathrm{H} 8$ & 2.08 & 2.18 & 0.10 & $x, y, 1+z$ \\
$\mathrm{H} 9 \cdots \mathrm{C} 1$ & 2.60 & 2.79 & 0.19 & $1-x, 1-y, 1-z$ \\
$\mathrm{C} 5 \cdots \mathrm{O} 3$ & 3.17 & 3.22 & 0.05 & $1-x,-y, 1-z$ \\
$\mathrm{H} 2 A \cdots \mathrm{S} 1$ & 2.87 & 2.89 & 0.02 & $1-x, 1-y, 2-z$ \\
$\mathrm{H} 9 \cdots \mathrm{S} 1$ & 2.89 & 2.89 & 0.00 & $1-x, 1-y, 1-z$ \\
\hline
\end{tabular}

Notes: (a) The interatomic distances are calculated in Crystal Explorer 17 (Turner et al., 2017) whereby the $X-\mathrm{H}$ bond lengths are adjusted to their neutron values; $(b)$ these interactions correspond to conventional hydrogen bonds.

formation of 12-membered $\{\cdots \mathrm{HO} \cdots \mathrm{HNCS}\}_{2}$ and 14membered $\left\{\cdots \mathrm{OC}_{2} \mathrm{NCNH}\right\}_{2}$ synthons, each disposed about a centre of inversion, and linked via the edges defined by the amine- $\mathrm{N}-\mathrm{H} \cdots \mathrm{O}$ (hydroxyl) hydrogen bonds. The tape has a step-ladder topology and projecting laterally to either side of the tape are the remaining amine- $\mathrm{H}$ and carbonyl- $\mathrm{O}$ atoms, which form the donors and acceptors of amine-N$\mathrm{H}$-.. O (carbonyl) hydrogen bonds to link the tapes into a layer in the $a c$ plane, Fig. 2(b). The directional links between layers are twofold, namely $\pi-\pi$ stacking between the centrosymmetrically related benzene rings [inter-centroid separation $=3.8722(7)^{\circ}$ for symmetry operation $\left.2-x, 1-y, 1-z\right]$ and parallel $\mathrm{C}=\mathrm{O} \cdots \pi$ interactions, Table 1 and Fig. 2(c). These interactions are possible owing to the inter-digitation of the benzene rings along the $b$-axis direction, as highlighted in Fig. 2(d).

\section{Hirshfeld surface analysis}

Structure (I) was subjected to a Hirshfeld surface analysis in order to gain further understanding into the molecular interactions existing within the crystal. This was achieved through Crystal Explorer 17 (Turner et al., 2017) using established methods (Tan, Jotani et al., 2019). A list of $d_{\text {norm }}$ contact distances for all identified interactions is given in Table 2. As noted from Fig. 3, several red spots of variable intensity were identified on the Hirshfeld surface of (I), being indicative of close interactions with contact distances shorter than the sum of the respective van der Waals (vdW) radii (Spackman \& Jayatilaka, 2009). In particular, the most intense red spot is observed for the amine- $\mathrm{N} 1-\mathrm{H} 2 \mathrm{~N}$...O1(hydroxyl) hydrogen bond with a $d_{\text {norm }}$ distance of $1.92 \AA$, which is significantly shorter, by $0.69 \AA\left[=\Delta\left|\left(d_{\text {norm }}-\Sigma v d W\right)_{\mathrm{H} \ldots \mathrm{O}}\right|\right.$ in Table 2], than the vdW value of $2.61 \AA$ (adjusted to neutron values). Other prominent features are due to the hydroxyl-O1$\mathrm{H} 1 O \cdots \mathrm{S} 1$ (thione) and amine-N1-H1N..O3(carbonyl) hydrogen bonds. Less intense features on the $d_{\text {norm }}$ maps of Fig. 3 are due to benzene-C9-H9 ..C1(thione) and methylene-C3-H3B $\cdots \mathrm{H} 8$ (benzene) interactions, and the diminutive spots arise from weaker methylene-C5..O3(carbonyl), methylene-C2- $\mathrm{H} 2 A \cdots \mathrm{S} 1$ (thione) and benzene-C9H9...S1(thione) contacts at distances just shorter or approximately equivalent to the values of the respective
$\Sigma$ vdW radii. Apart from the conventional hydrogen bonds and other interactions involving hydrogen, several interactions involving the aromatic ring are apparent.

Thus, $\pi$ (benzene) $-\pi$ (benzene) interactions, with an intercentroid separation $=3.8722(7) \AA$, as well as parallel $\mathrm{C} 6=\mathrm{O} 3 \cdots \mathrm{Cg}(\mathrm{C} 7-\mathrm{C} 11)$ interactions, occurring on either side of a reference benzene ring, are validated through further Hirshfeld surface analysis. The presence of $\pi-\pi$ interactions are supported by the shape complementarity between the aromatic rings as evidenced from the planar stacking arrangement illustrated through the Hirshfeld surface mapped with curvedness in Fig. 4(a). As for the $\mathrm{C}=\mathrm{O} \cdots \pi$ interaction, the shape-index on the Hirshfeld surface reveals that there are

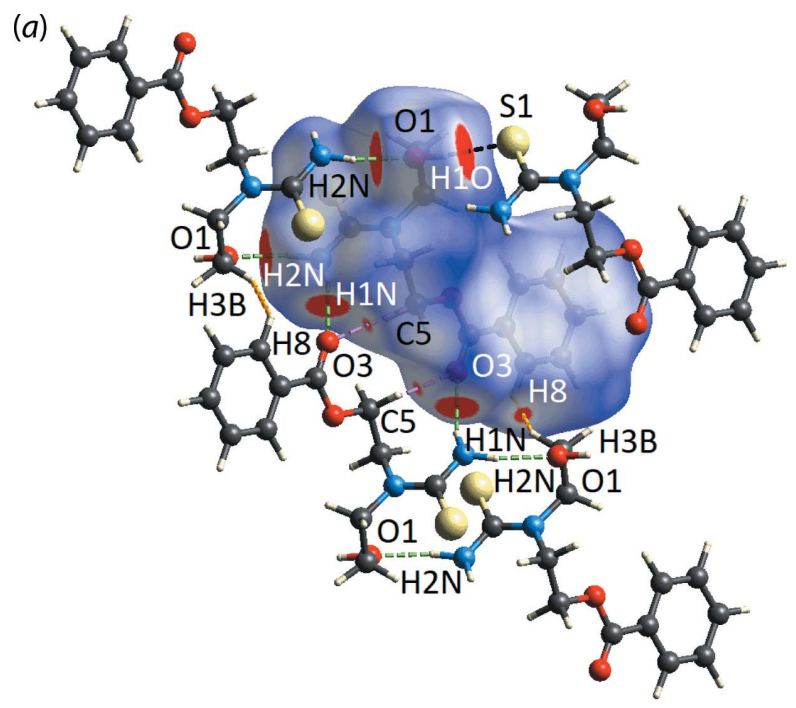

(b)

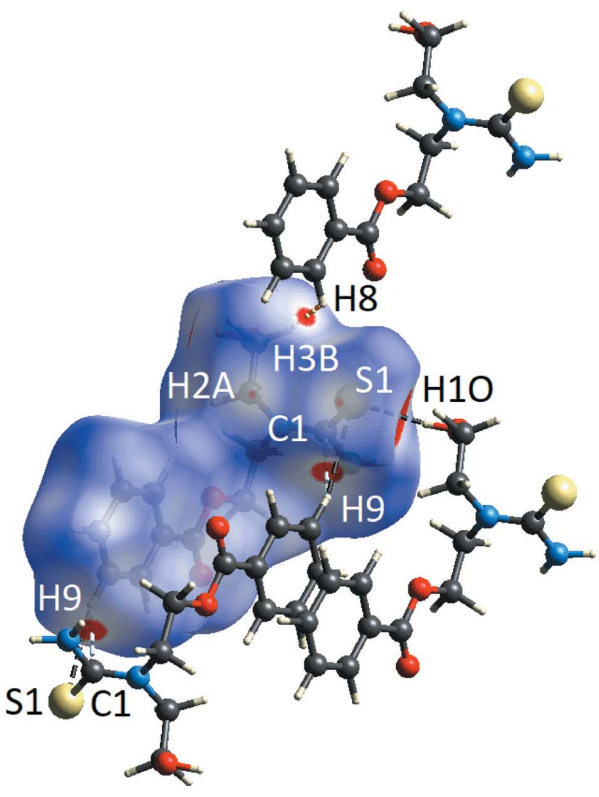

Figure 3

The two views of the $d_{\text {norm }}$ maps for (I), showing the relevant short contacts indicated by the red spots on the Hirshfeld surface with varying intensities within the range -0.0322 to 1.1699 arbitrary units for $(a)$ $\mathrm{H} 1 B \cdots \mathrm{O} 1, \mathrm{H} 1 O \cdots \mathrm{S} 1, \mathrm{H} 1 A \cdots \mathrm{O} 3, \mathrm{C} 5 \cdots \mathrm{O} 3$ and $\mathrm{H} 3 B \cdots \mathrm{H} 8$ and $(b)$ $\mathrm{H} 9 \cdots \mathrm{C} 1, \mathrm{H} 9 \cdots \mathrm{S} 1$ as well as $\mathrm{H} 2 A \cdots \mathrm{S} 1$ (not connected for clarity). All $\mathrm{H} \cdots \mathrm{O} / \mathrm{O} \cdots \mathrm{H}$ interactions are indicated in green, $\mathrm{H} \cdots \mathrm{S} / \mathrm{S} \cdots \mathrm{H}$ in black, $\mathrm{H} \cdots \mathrm{C} / \mathrm{C} \cdots \mathrm{H}$ in light blue, $\mathrm{C} \cdots \mathrm{O} / \mathrm{O} \cdots \mathrm{C}$ in pink and $\mathrm{H} \cdots \mathrm{H}$ in orange. 
Table 3

Electrostatic potential charge $\left(V_{\mathrm{ESP}}\right)$ for each hydrogen atom donor and acceptor in (I) participating in a close contact identified through Hirshfeld surface analysis.

\begin{tabular}{|c|c|c|c|}
\hline \multirow[t]{2}{*}{ Contact } & \multicolumn{2}{|c|}{ Electrostatic potential, $V_{\mathrm{ESP}}$ (a.u.) } & \multirow[t]{2}{*}{$\Delta\left|V_{\mathrm{ESP}}\right|$} \\
\hline & H-donor & H-acceptor & \\
\hline $\mathrm{H} 2 N \cdots \mathrm{O} 1$ & 0.1446 & -0.0654 & 0.2100 \\
\hline $\mathrm{H} 1 O \cdots \mathrm{S} 1$ & 0.1488 & -0.0607 & 0.2095 \\
\hline $\mathrm{H} 1 N \cdots \mathrm{O} 3$ & 0.1248 & -0.0601 & 0.1849 \\
\hline $\mathrm{H} 9 \cdots \mathrm{C} 1$ & 0.0441 & -0.0119 & 0.0560 \\
\hline $\mathrm{H} 3 B \cdots \mathrm{H} 8$ & 0.0066 & 0.0229 & 0.0163 \\
\hline $\mathrm{C} 5 \cdots \mathrm{O} 3$ & 0.0581 & -0.0562 & 0.1143 \\
\hline $\mathrm{H} 2 A \cdots \mathrm{S} 1$ & 0.0239 & -0.0589 & 0.0828 \\
\hline H9...S1 & 0.0219 & -0.0458 & 0.0677 \\
\hline
\end{tabular}

complementary concave and convex shapes indicated by the red and blue regions around the centre of aromatic ring and ester-C6 atom, respectively, in Fig. 4(b). This suggests the
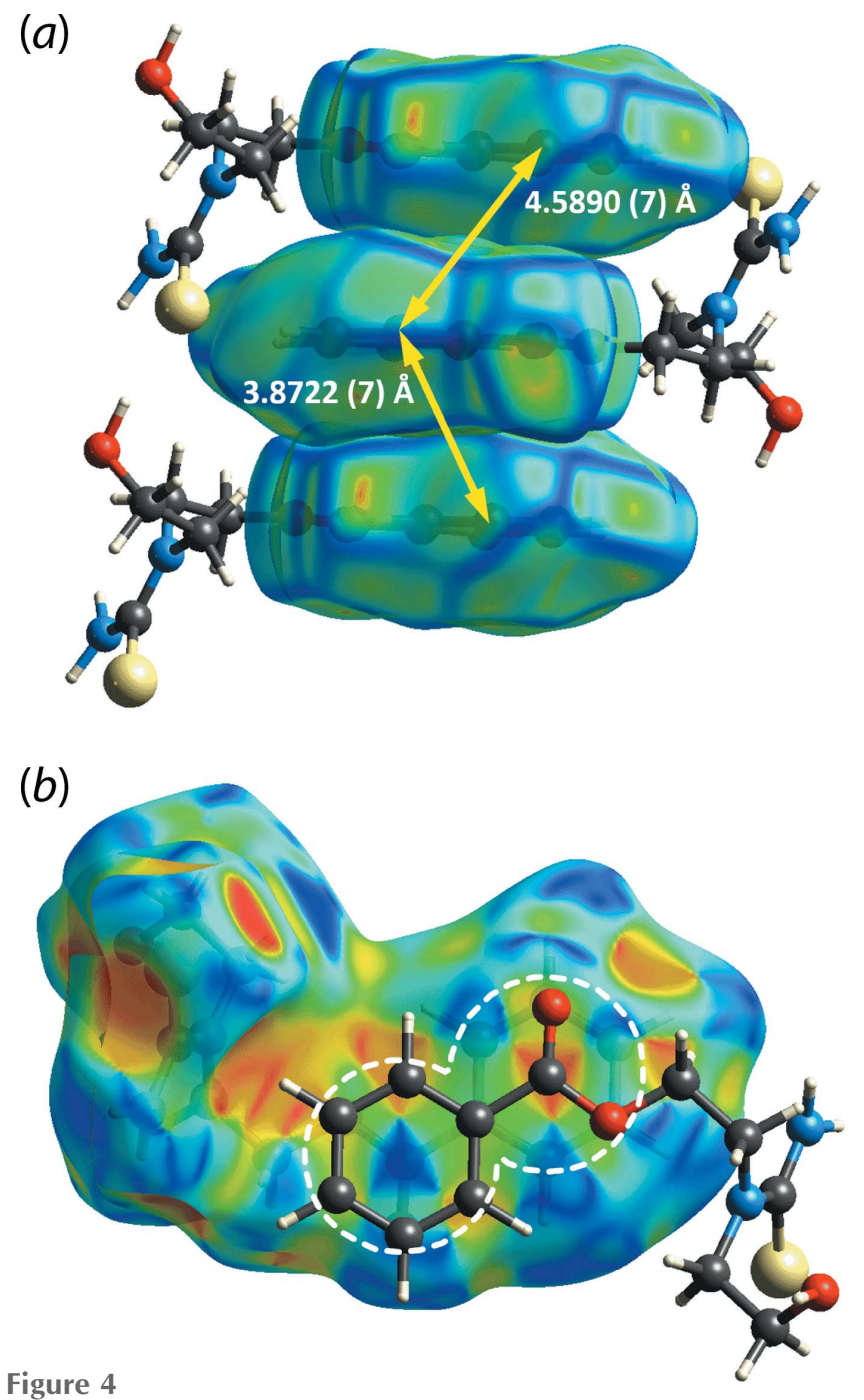

(a) The Hirshfeld surface mapped with curvedness (property range: -4.0 to +0.4 arbitrary units) for the benzoate fragments of (I), showing the shape complementarity for the $\pi-\pi$ stacking between the fragments and (b) the shape-index (property range: -1.0 to +1.0 arbitrary units) on the Hirshfeld surface of (I), showing the concave (red) and convex (blue) regions indicating the $\mathrm{C} \cdots \mathrm{O}$ shape complementary interaction (circled).
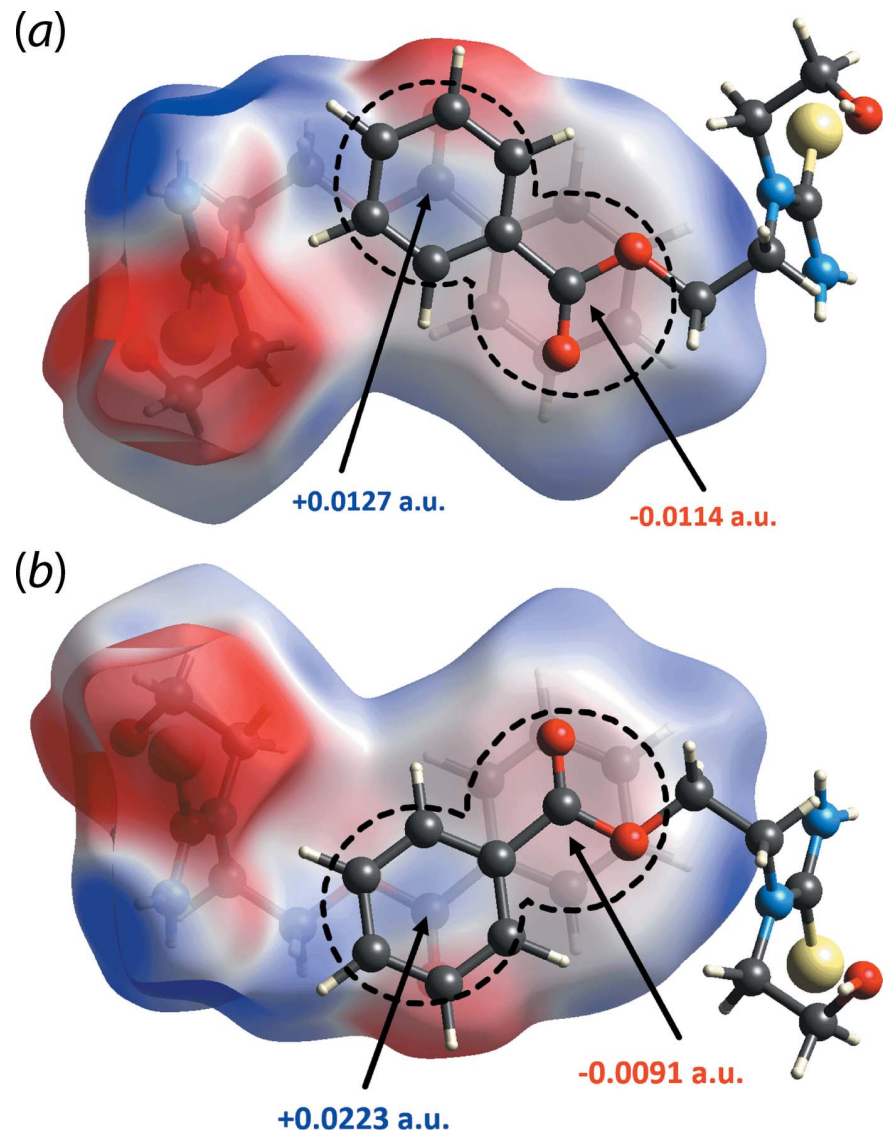

Figure 5

The electrostatic potential mapped onto the Hirshfeld surface for (I) within the range -0.0672 to 0.0620 atomic units for $(a)$ the upper side of the ester group (circled blue region) and $\pi$-ring system (circled red region) and (b) the reverse sides of the ester group (circled faint-blue region) and $\pi$-ring system (circled faint-red region). The images highlight the charge complementarity between the specified interactions.

interaction could involve a significant contribution from the C6 atom; the C6 $\cdots C g$ (benzene) separation is 3.5026 (11) $\AA$ as opposed to the $\mathrm{O} 3 \cdots \mathrm{Cg}$ (benzene) separation of 3.6604 (10) Å, Table 1 .

In order to confirm the above findings, particularly the short contacts as well as the interactions involving the aromatic ring, electrostatic potential (ESP) mapping was also performed on the Hirshfeld surface using the DFT-B3LYP quantum level of theory and 6-31G $(d, p)$ basis set as available in Crystal Explorer 17 (Turner et al., 2017). The ESP charge for each $\mathrm{H}$ atom donor and acceptor of the relevant close contacts are tabulated in Table 3. As expected for the conventional hydrogen bonds detected through PLATON (Spek, 2020), significant differences are observed in the electrostatic potentials of the hydrogen-bond donor and acceptor atoms, indicating a strong attraction. Similar observations are noted for the other identified contacts but with smaller differences with the notable exception of the methylene-C3$\mathrm{H} 3 B \cdots \mathrm{H} 8$ (benzene) contact, for which both interacting hydrogen atoms exhibit a positive electrostatic potential signifying that the interaction is dispersive in nature. As for the $\pi-\pi$ interaction, it has already been established that the 
Table 4

A summary of interaction energies $\left(\mathrm{kJ} \mathrm{mol}^{-1}\right)$ calculated for (I).

\begin{tabular}{|c|c|c|c|c|c|c|}
\hline Contact & $E_{\text {ele }}$ & $E_{\text {pol }}$ & $E_{\text {dis }}$ & $E_{\text {rep }}$ & $E_{\text {tot }}$ & Symmetry operation \\
\hline$\{\mathrm{N} 1-\mathrm{H} 2 \mathrm{~N} \cdots \mathrm{O} 1\}_{2}$ & -91.6 & -13.5 & -39.5 & 59.1 & -85.6 & $1-x,-y, 2-z$ \\
\hline$\{\mathrm{N} 1-\mathrm{H} 1 N \cdots \mathrm{O} 3\}_{2}+\{\mathrm{C} 5 \cdots \mathrm{O} 3\}_{2}$ & -56.9 & -10.1 & -26.5 & 27.4 & -66.1 & $1-x,-y, 1-z$ \\
\hline $\begin{array}{l}\mathrm{C} 6 \cdots \pi \text { (benzene) }+ \\
\{\mathrm{C} 9-\mathrm{H} 9 \cdots \mathrm{S} 1\}_{2}+\end{array}$ & & & & & & \\
\hline$\{\mathrm{C} 9-\mathrm{H} 9 \cdots \mathrm{C} 1\}_{2}$ & -21.6 & -3.0 & -57.1 & 33.2 & -48.3 & $1-x, 1-y, 1-z$ \\
\hline $\mathrm{O} 1-\mathrm{H} 1 O \cdots \mathrm{S} 1$ & -47.2 & -7.5 & -10.6 & 36.5 & -28.8 & $1+x, y, z$ \\
\hline$\pi$ (benzene $)-\pi($ benzene $)$ & -0.4 & -1.6 & -43.2 & 17.0 & -28.3 & $2-x, 1-y, 1-z$ \\
\hline$\{\mathrm{C} 2-\mathrm{H} 2 A \cdots \mathrm{S} 1\}_{2}$ & -14.6 & -5.1 & -14.7 & 11.3 & -23.1 & $1-x, 1-y, 2-z$ \\
\hline $\mathrm{C} 3-\mathrm{H} 3 B \cdots \mathrm{H} 8$ & 1.1 & -1.8 & -12.7 & 9.1 & -4.3 & $x, y, 1+z$ \\
\hline
\end{tabular}

contacts arise to charge complementarity between the rings. Concerning the $\mathrm{C}=\mathrm{O} 3 \cdots \pi$ contact, occurring between benzene rings separated by an inter-centroid separation of 4.5890 (7) $\AA$, the ester-C6 atom exhibits positive ESP of +0.0127 a.u. on one side to complement the negative ESP of -0.0114 a.u. at the centre of the aromatic ring it interacts with, Fig. 5(a). At the same time it has an ESP charge of +0.0223 a.u. on the reverse side that complements the other side of a symmetry related aromatic ring, involved in the $\pi-\pi$ contact with an inter-centroid distance of 3.8722 (7) $\AA$, with the ESP charge of -0.0091 a.u., Fig. 5(b).

The close contacts were also investigated through fingerprint plot analysis, shown in the upper views of Fig. 6. The $d_{\text {norm-mapped Hirshfeld surfaces for the most prominent }}$ point-to-point interactions, giving rise to the most discernible peaks in the fingerprint plots, are shown in the lower views of Fig. 6. In general, (I) exhibits a paw-like, overall fingerprint profile, Fig. 6(a), which can be mainly delineated into $\mathrm{H} \cdots \mathrm{H}$ $(51.1 \%), \mathrm{H} \cdots \mathrm{O} / \mathrm{O} \cdots \mathrm{H}(14.6 \%), \mathrm{H} \cdots \mathrm{S} / \mathrm{S} \cdots \mathrm{H}(14.5 \%)$, $\mathrm{H} \cdots \mathrm{C} / \mathrm{C} \cdots \mathrm{H}(7.2 \%), \mathrm{C} \cdots \mathrm{C}(6.0 \%)$ contacts, Fig. $6(b)-(e)$, as well as other minor contacts which constitute about $6.0 \%$ of the remaining contacts. A further analysis on the respective fingerprint plots shows that the distribution for the (internal)$\mathrm{O} \cdot \mathrm{H}$-(external), (internal)-S..H-(external) and (internal)C. $\cdot \mathrm{H}$-(external) are slightly more dominant than the (internal)-H $\cdots X$-(external) counterparts $(X=\mathrm{O}, \mathrm{S}$, and $\mathrm{C})$, with the distribution being $8.0,9.3$ and $4.0 \%$ as against $6.6,5.2$ and $3.2 \%$, respectively. These results tally with the fact that (I) has more hydrogen-bond acceptors than hydrogen-bond donor atoms. Nonetheless, both (internal)- $X \cdots \mathrm{H}$-(external) and (internal)-H $\cdots X$-(external) exhibit equivalent contact distances that are tipped at the minimum $d_{\mathrm{i}}+d_{\mathrm{e}}$ values, which correspond to the specified contacts in Table 2.

\section{Computational chemistry}

The calculation of the interaction energy for all pairwise molecules in (I) was performed through Crystal Explorer 17 (Turner et al., 2017) with the purpose of studying the strength of each interaction/set of interactions identified from the Hirshfeld surface analysis. Hence, the electrostatic $\left(E_{\text {ele }}\right)$, polarization $\left(E_{\mathrm{pol}}\right)$, dispersion $\left(E_{\mathrm{dis}}\right)$ and exchange-repulsion $\left(E_{\text {rep }}\right)$ terms were calculated with the results tabulated in Table 4. (a)

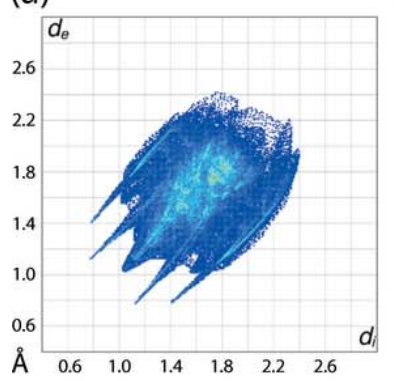

(b)
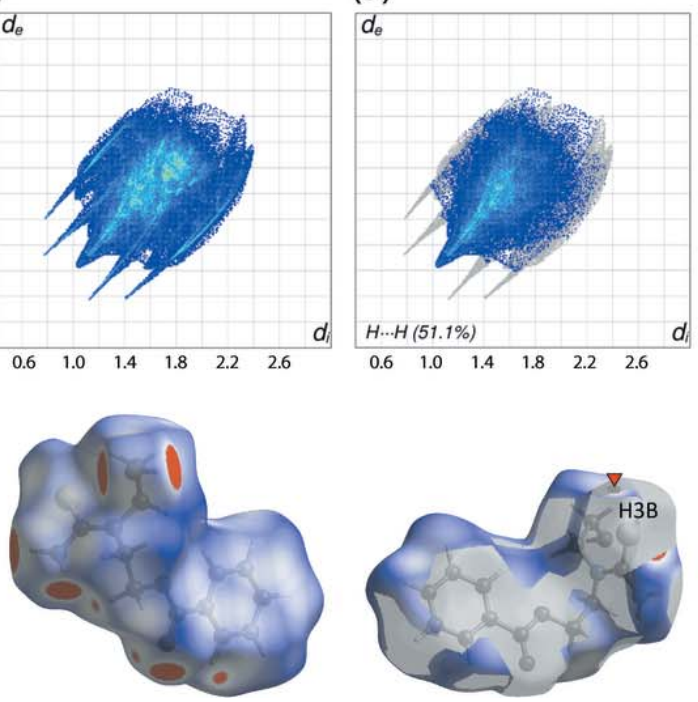

(c)
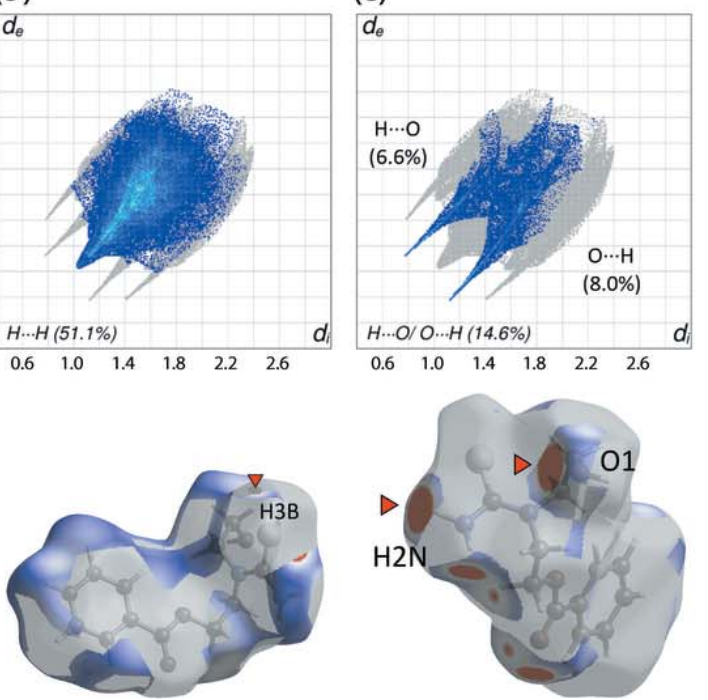

(d)

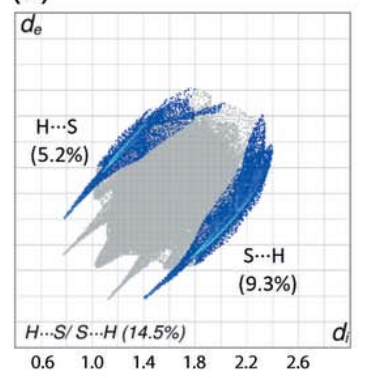

(e)
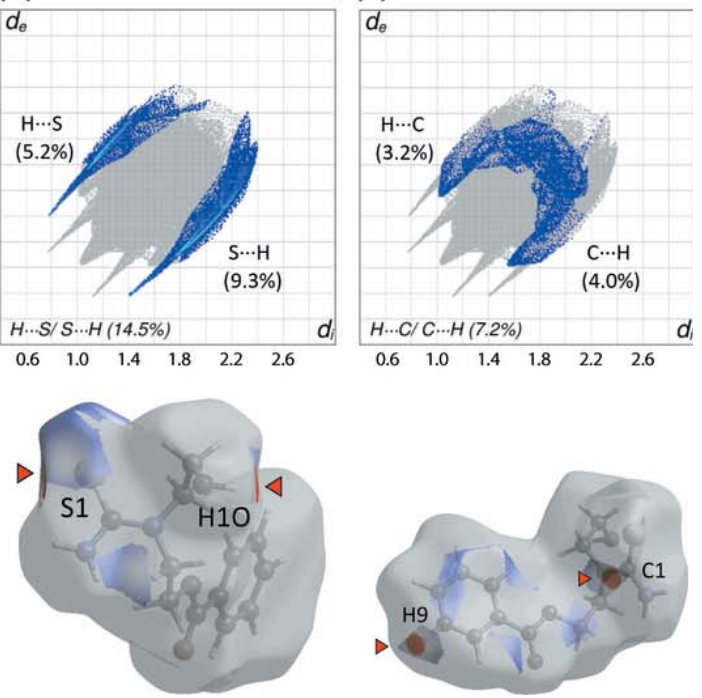

Figure 6

Upper view: (a) The overall two-dimensional fingerprint plot for (I) and those delineated into $(b) \mathrm{H} \cdots \mathrm{H},(c) \mathrm{H} \cdots \mathrm{O} / \mathrm{O} \cdots \mathrm{H},(d) \mathrm{H} \cdots \mathrm{S} / \mathrm{S} \cdots \mathrm{H}$ and $(\mathrm{e})$ $\mathrm{H} \cdots \mathrm{C} / \mathrm{C} \cdots \mathrm{H},(e)$ contacts, with the percentage contributions to the overall surface specified within each plot. Lower views: $d_{\text {norm }}$ maps where the tip of the delineated fingerprint plot corresponds to the relevant contact on the Hirshfeld surface and identified through the red cursors. 

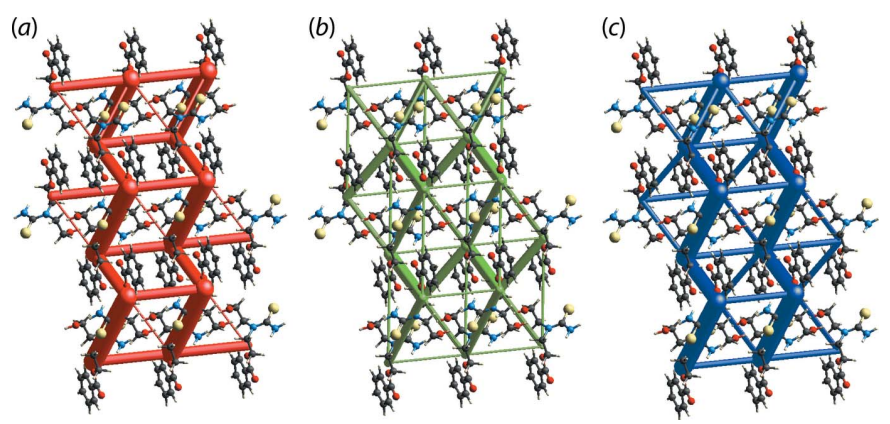

Figure 7

Perspective views of the energy frameworks of (I), showing the (a) electrostatic force, $(b)$ dispersion force and $(c)$ total energy. The radii of the cylinders are proportional to the relative strength of the corresponding energies and were adjusted to the same scale factor of 100 with a cut-off value of $8 \mathrm{~kJ} \mathrm{~mol}^{-1}$ within a $2 \times 2 \times 2$ unit cells.

Among all the interactions, it is the amine-N1$\mathrm{H} 2 \mathrm{~N}$...O1(hydroxyl) hydrogen bond, that closes the connected 12-membered $\{\cdots \mathrm{HO} \cdots \mathrm{HNCS}\}_{2}$ and 14membered $\left\{\cdots \mathrm{OC}_{2} \mathrm{NCNH}\right\}_{2}$ synthons, that has the greatest interaction energy, $E_{\mathrm{int}}=-85.6 \mathrm{~kJ} \mathrm{~mol}^{-1}$. Next most stabilizing are the amine-N1-H1N...O3(carbonyl) and methylene-C5..O3(carbonyl) contacts between centrosymmetrically related molecules $\left[-66.1 \mathrm{~kJ} \mathrm{~mol}^{-1}\right]$, the ester-

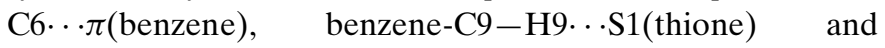
benzene-C9-H9 ..C1(thione) contacts with a combined $E_{\text {int }}$ of $-48.3 \mathrm{~kJ} \mathrm{~mol}^{-1}$ and hydroxyl-O1-H1O $\cdots \mathrm{S} 1$ (thione) $\left[-28.8 \mathrm{~kJ} \mathrm{~mol}^{-1}\right]$. Close in energy to latter is that due to $\pi-\pi$ $[C g 1 \cdots C g 1=3.8722(7) \AA]$ with $E_{\text {int }}=-28.3 \mathrm{~kJ} \mathrm{~mol}^{-1}$. Next most significant are the pairwise ethylene-C2$\mathrm{H} 2 A \cdots \mathrm{S} 1$ (thione) interactions $\left(E_{\mathrm{int}}=-23.1 \mathrm{~kJ} \mathrm{~mol}^{-1}\right)$ then methylene-C3-H3B $\cdots \mathrm{H} 8$ (benzene) $\left(E_{\mathrm{int}}=-4.3 \mathrm{~kJ} \mathrm{~mol}^{-1}\right)$.

The crystal of (I) is mainly sustained by electrostatic forces owing to the presence of the relatively strong hydrogenbonding interactions, viz. amine-N1-H1N..OO3(carbonyl) that propagates along the $c$ axis together with amine-N1$\mathrm{H} 2 N \cdots \mathrm{O} 1$ (hydroxyl) and hydroxyl-O1-H1O ..S1(thione),<smiles>CNC(=S)N(CCO)Cc1ccc(C(=O)c2ccccc2)cc1</smiles>

(II)<smiles>OCCN1CCNC1=S</smiles>

(III)

Figure 8

Chemical diagrams for (II) and (III).
Table 5

Experimental details.

\begin{tabular}{|c|c|}
\hline \multicolumn{2}{|l|}{ Crystal data } \\
\hline Chemical formula & $\mathrm{C}_{12} \mathrm{H}_{16} \mathrm{~N}_{2} \mathrm{O}_{3} \mathrm{~S}$ \\
\hline$M_{\mathrm{r}}$ & 268.33 \\
\hline Crystal system, space group & Triclinic, $P \overline{1}$ \\
\hline Temperature (K) & 100 \\
\hline$a, b, c(\AA)$ & $7.1608(2), 8.8771(2), 10.0728(2)$ \\
\hline$\alpha, \beta, \gamma\left({ }^{\circ}\right)$ & $96.815(2), 96.057(2), 95.990(2)$ \\
\hline$V\left(\AA^{3}\right)$ & $627.78(3)$ \\
\hline$Z$ & 2 \\
\hline Radiation type & $\mathrm{Cu} K \alpha$ \\
\hline$\mu\left(\mathrm{mm}^{-1}\right)$ & 2.33 \\
\hline Crystal size $(\mathrm{mm})$ & $0.14 \times 0.10 \times 0.09$ \\
\hline \multicolumn{2}{|l|}{ Data collection } \\
\hline Diffractometer & $\begin{array}{l}\text { XtaLAB Synergy, Dualflex, } \\
\text { AtlasS2 }\end{array}$ \\
\hline Absorption correction & $\begin{array}{l}\text { Gaussian (CrysAlis PRO; Rigaku } \\
\text { OD, 2018) }\end{array}$ \\
\hline$T_{\min }, T_{\max }$ & $0.656,1.000$ \\
\hline $\begin{array}{l}\text { No. of measured, independent and } \\
\text { observed }[I>2 \sigma(I)] \text { reflections }\end{array}$ & $15863,2608,2530$ \\
\hline$R_{\text {int }}$ & 0.028 \\
\hline$(\sin \theta / \lambda)_{\max }\left(\AA^{-1}\right)$ & 0.631 \\
\hline \multicolumn{2}{|l|}{ Refinement } \\
\hline$R\left[F^{2}>2 \sigma\left(F^{2}\right)\right], w R\left(F^{2}\right), S$ & $0.027,0.072,1.02$ \\
\hline No. of reflections & 2608 \\
\hline No. of parameters & 172 \\
\hline No. of restraints & 3 \\
\hline $\mathrm{H}$-atom treatment & $\begin{array}{l}\mathrm{H} \text { atoms treated by a mixture of } \\
\text { independent and constrained } \\
\text { refinement }\end{array}$ \\
\hline$\Delta \rho_{\max }, \Delta \rho_{\min }\left(\mathrm{e} \AA^{-3}\right)$ & $0.28,-0.29$ \\
\hline
\end{tabular}

Computer programs: CrysAlis PRO (Rigaku OD, 2018), SHELXS (Sheldrick, 2015a), SHELXL2018/3 (Sheldrick, 2015b), ORTEP-3 for Windows (Farrugia, 2012), DIAMOND (Brandenburg, 2006) andpublCIF (Westrip, 2010).

which extend along the $a$ axis, thereby forming a step-ladder framework as shown in Fig. 7(a). On the other hand, significant dispersion force is also present as evidenced from the wire mesh-like dispersion energy framework predominantly governed by the $\pi-\pi$ interactions, with contributions from the interactions involving the benzene-C9 atom, Fig. 7(b). Overall, the combination of electrostatic and dispersion forces leads to a cuboid-like framework shown in Fig. 7(c).

\section{Database survey}

Crystal-structure determinations of organic molecules of the general formula $R\left(R^{\prime}\right) \mathrm{NC}(=\mathrm{S}) \mathrm{NH}_{2}$ are comparatively rare with the simplest derivative being the $R=R^{\prime}=$ Me species, the almost planar molecule being first reported in 1994 (WIFKOL; Pathirana et al., 1994). Similarly, derivatives bearing hydroxyl groups are uncommon and include the relatively simple derivatives shown in Fig. 8, i.e. acyclic (II) (IYAYAJ; Griffiths et al., 2010) and cyclic imidazolidine-2-thione (III) (DOJSUT; Lee et al., 2018).

\section{Synthesis and crystallization}

Compound (I) was synthesized by gently heating an acetone mixture $(30 \mathrm{ml})$ containing ammonium thiocyanate (Fisher, $1 \mathrm{mmol}$ ), benzoyl chloride (Acros, $1 \mathrm{mmol}$ ) and bis(hydroxy- 
ethyl)amine (Acros, $1 \mathrm{mmol}$ ). The solution was concentrated to half of the initial volume under heating and a white precipitate was obtained upon cooling the solution to room temperature. Colourless blocks were formed through recrystallization of the crude product from acetone solution. M.p. 388.6-390.1 K. IR $\left(\mathrm{cm}^{-1}\right): 3419 v(\mathrm{OH}), 3323 v\left(\mathrm{NH}_{2}\right)_{\text {asym }}, 3222$ $v\left(\mathrm{NH}_{2}\right)_{\text {sym }}, 3058 v(\mathrm{CH})_{\text {arom }}, 3002-2881 v(\mathrm{CH}), 1706 v(\mathrm{COO})$, $1647 v(\mathrm{C}=\mathrm{O}), 1600 \delta(\mathrm{NH}), 1523 v(\mathrm{C}=\mathrm{C}), 1270 v(\mathrm{CN}), 1053$ $v(\mathrm{C}=\mathrm{S}), 711 \delta(\mathrm{CH})$.

\section{Refinement}

Crystal data, data collection and structure refinement details are summarized in Table 5. The carbon-bound $\mathrm{H}$ atoms were placed in calculated positions $(\mathrm{C}-\mathrm{H}=0.95-0.98 \AA)$ and were included in the refinement in the riding-model approximation, with $U_{\text {iso }}(\mathrm{H})$ set to $1.2 U_{\text {eq }}(\mathrm{C})$. The oxygen- and nitrogenbound $\mathrm{H}$ atoms were located from a difference-Fourier map and refined with $\mathrm{O}-\mathrm{H}=0.84 \pm 0.01 \AA$ and $\mathrm{N}-\mathrm{H}=$ $0.88 \pm 0.01 \AA$, and with $U_{\text {iso }}(\mathrm{H})$ set to $1.5 U_{\text {eq }}(\mathrm{O})$ or $1.2 U_{\text {eq }}(\mathrm{N})$.

\section{Funding information}

Crystallographic research at Sunway University is supported by Sunway University Sdn Bhd (grant No. STR-RCTRRCCM-001-2019).

\section{References}

Brandenburg, K. (2006). DIAMOND. Crystal Impact GbR, Bonn, Germany.

Farrugia, L. J. (2012). J. Appl. Cryst. 45, 849-854.

Griffiths, J.-P., Maliha, B., Moloney, M. G., Thompson, A. L. \& Hussain, I. (2010). Langmuir, 26, 14142-14153.

Lee, S. M., Azizan, A. H. S. \& Tiekink, E. R. T. (2018). Molbank 2018, article No. M1035.

Pathirana, H. M. K. K., Weiss, T. J., Reibenspies, J. H., Zingaro, R. A. \& Meyers, E. A. (1994). Z. Kristallogr. Cryst. Mater. 209, 698.

Rigaku OD (2018). CrysAlis PRO Software system. Rigaku Corporation, Oxford, UK.

Saeed, A., Flörke, U. \& Erben, M. F. (2014). J. Sulfur Chem. 35, 318355.

Sheldrick, G. M. (2015a). Acta Cryst. A71, 3-8.

Sheldrick, G. M. (2015b). Acta Cryst. C71, 3-8.

Spackman, M. A. \& Jayatilaka, D. (2009). CrystEngComm, 11, 1932.

Spek, A. L. (2020). Acta Cryst. E76, 1-11.

Tan, S. L., Azizan, A. H. S., Jotani, M. M. \& Tiekink, E. R. T. (2019). Acta Cryst. E75, 1472-1478.

Tan, S. L., Jotani, M. M. \& Tiekink, E. R. T. (2019). Acta Cryst. E75, 308-318.

Tan, S. L., Jotani, M. M. \& Tiekink, E. R. T. (2020). Acta Cryst. E76, $155-161$.

Turner, M. J., Mckinnon, J. J., Wolff, S. K., Grimwood, D. J., Spackman, P. R., Jayatilaka, D. \& Spackman, M. A. (2017). Crystal Explorer 17. The University of Western Australia.

Westrip, S. P. (2010). J. Appl. Cryst. 43, 920-925. 


\section{supporting information}

Acta Cryst. (2020). E76, 933-939 [https://doi.org/10.1107/S2056989020006829]

\section{2-[Carbamothioyl(2-hydroxyethyl)amino] ethyl benzoate: crystal structure, Hirshfeld surface analysis and computational study}

\section{Sang Loon Tan and Edward R. T. Tiekink}

Computing details

Data collection: CrysAlis PRO (Rigaku OD, 2018); cell refinement: CrysAlis PRO (Rigaku OD, 2018); data reduction: CrysAlis PRO (Rigaku OD, 2018); program(s) used to solve structure: SHELXS (Sheldrick, 2015a); program(s) used to refine structure: SHELXL2018/3 (Sheldrick, 2015b); molecular graphics: ORTEP-3 for Windows (Farrugia, 2012), DIAMOND (Brandenburg, 2006); software used to prepare material for publication: publCIF (Westrip, 2010).

2-[Carbamothioyl(2-hydroxyethyl)amino]ethyl benzoate

\section{Crystal data}

$\mathrm{C}_{12} \mathrm{H}_{16} \mathrm{~N}_{2} \mathrm{O}_{3} \mathrm{~S}$

$M_{r}=268.33$

Triclinic, $P \overline{1}$

$a=7.1608(2) \AA$

$b=8.8771(2) \AA$

$c=10.0728(2) \AA$

$\alpha=96.815(2)^{\circ}$

$\beta=96.057(2)^{\circ}$

$\gamma=95.990(2)^{\circ}$

$V=627.78(3) \AA^{3}$

\section{Data collection}

XtaLAB Synergy, Dualflex, AtlasS2 diffractometer

Radiation source: micro-focus sealed X-ray tube, PhotonJet $(\mathrm{Cu}) \mathrm{X}$-ray Source

Mirror monochromator

Detector resolution: 5.2558 pixels $\mathrm{mm}^{-1}$

$\omega$ scans

Absorption correction: gaussian

(CrysAlisPro; Rigaku OD, 2018)

\section{Refinement}

Refinement on $F^{2}$

Least-squares matrix: full

$R\left[F^{2}>2 \sigma\left(F^{2}\right)\right]=0.027$

$w R\left(F^{2}\right)=0.072$

$S=1.02$

2608 reflections

172 parameters

3 restraints
$Z=2$

$F(000)=284$

$D_{\mathrm{x}}=1.420 \mathrm{Mg} \mathrm{m}^{-3}$

$\mathrm{Cu} K \alpha$ radiation, $\lambda=1.54184 \AA$

Cell parameters from 11731 reflections

$\theta=5.0-76.3^{\circ}$

$\mu=2.33 \mathrm{~mm}^{-1}$

$T=100 \mathrm{~K}$

Block, colourless

$0.14 \times 0.10 \times 0.09 \mathrm{~mm}$

$T_{\min }=0.656, T_{\max }=1.000$

15863 measured reflections

2608 independent reflections

2530 reflections with $I>2 \sigma(I)$

$R_{\text {int }}=0.028$

$\theta_{\max }=76.6^{\circ}, \theta_{\min }=4.5^{\circ}$

$h=-8 \rightarrow 9$

$k=-11 \rightarrow 11$

$l=-12 \rightarrow 11$

Primary atom site location: structure-invariant direct methods

Secondary atom site location: difference Fourier map

Hydrogen site location: mixed

$\mathrm{H}$ atoms treated by a mixture of independent and constrained refinement 
$w=1 /\left[\sigma^{2}\left(F_{\mathrm{o}}^{2}\right)+(0.0387 P)^{2}+0.2837 P\right]$

where $P=\left(F_{\mathrm{o}}^{2}+2 F_{\mathrm{c}}^{2}\right) / 3$

$(\Delta / \sigma)_{\max }=0.001$

$$
\Delta \rho_{\max }=0.28 \mathrm{e} \AA^{-3}
$$

\section{Special details}

Geometry. All esds (except the esd in the dihedral angle between two 1.s. planes) are estimated using the full covariance matrix. The cell esds are taken into account individually in the estimation of esds in distances, angles and torsion angles; correlations between esds in cell parameters are only used when they are defined by crystal symmetry. An approximate (isotropic) treatment of cell esds is used for estimating esds involving l.s. planes.

Fractional atomic coordinates and isotropic or equivalent isotropic displacement parameters $\left(\hat{A}^{2}\right)$

\begin{tabular}{|c|c|c|c|c|}
\hline & $x$ & $y$ & $z$ & $U_{\text {iso }} * / U_{\text {eq }}$ \\
\hline S1 & $0.37572(4)$ & 0.27008 & $1.03290(3)$ & $0.01701(9)$ \\
\hline O1 & $0.95223(11)$ & $0.15258(9)$ & $1.06895(9)$ & $0.02017(19)$ \\
\hline $\mathrm{H} 1 \mathrm{O}$ & $1.0641(15)$ & 0.1717 (19) & $1.0521(17)$ & $0.030^{*}$ \\
\hline $\mathrm{O} 2$ & $0.70466(11)$ & $0.26850(9)$ & $0.61989(8)$ & $0.01658(17)$ \\
\hline $\mathrm{O} 3$ & $0.60618(13)$ & $0.20970(10)$ & $0.39867(8)$ & $0.02231(19)$ \\
\hline N1 & $0.35269(14)$ & $0.03143(11)$ & $0.84534(10)$ & $0.0167(2)$ \\
\hline $\mathrm{H} 1 \mathrm{~N}$ & $0.396(2)$ & $-0.0360(14)$ & $0.7896(13)$ & $0.020^{*}$ \\
\hline $\mathrm{H} 2 \mathrm{~N}$ & $0.2480(16)$ & $0.0025(16)$ & $0.8779(14)$ & $0.020^{*}$ \\
\hline N2 & $0.63866(13)$ & $0.18528(10)$ & $0.87909(9)$ & $0.01420(19)$ \\
\hline $\mathrm{C} 1$ & $0.46322(16)$ & $0.15473(12)$ & $0.91223(11)$ & $0.0146(2)$ \\
\hline $\mathrm{C} 2$ & $0.76658(16)$ & $0.31983(13)$ & $0.94513(12)$ & $0.0169(2)$ \\
\hline $\mathrm{H} 2 \mathrm{~A}$ & 0.692935 & 0.407323 & 0.960760 & $0.020^{*}$ \\
\hline $\mathrm{H} 2 \mathrm{~B}$ & 0.861614 & 0.347207 & 0.884739 & $0.020^{*}$ \\
\hline $\mathrm{C} 3$ & $0.86760(16)$ & $0.29131(13)$ & $1.07870(12)$ & $0.0183(2)$ \\
\hline $\mathrm{H} 3 \mathrm{~A}$ & 0.966872 & 0.377706 & 1.111775 & $0.022 *$ \\
\hline $\mathrm{H} 3 \mathrm{~B}$ & 0.775824 & 0.287765 & 1.145528 & $0.022 *$ \\
\hline $\mathrm{C} 4$ & $0.71451(16)$ & $0.08514(13)$ & $0.77635(11)$ & $0.0158(2)$ \\
\hline $\mathrm{H} 4 \mathrm{~A}$ & 0.676376 & -0.022672 & 0.787412 & $0.019^{*}$ \\
\hline H4B & 0.854379 & 0.103147 & 0.790497 & $0.019^{*}$ \\
\hline $\mathrm{C} 5$ & $0.64657(16)$ & $0.11088(13)$ & $0.63421(11)$ & $0.0170(2)$ \\
\hline $\mathrm{H} 5 \mathrm{~A}$ & 0.702102 & 0.042030 & 0.568493 & $0.020^{*}$ \\
\hline H5B & 0.507114 & 0.088915 & 0.617061 & $0.020^{*}$ \\
\hline C6 & $0.67210(15)$ & $0.30367(13)$ & $0.49377(11)$ & $0.0162(2)$ \\
\hline $\mathrm{C} 7$ & $0.72974(15)$ & $0.46730(13)$ & $0.48446(11)$ & $0.0158(2)$ \\
\hline $\mathrm{C} 8$ & $0.70318(16)$ & $0.51705(14)$ & $0.35804(12)$ & $0.0180(2)$ \\
\hline $\mathrm{H} 8$ & 0.641338 & 0.448875 & 0.282694 & $0.022 *$ \\
\hline C9 & $0.76728(17)$ & $0.66610(14)$ & $0.34284(12)$ & $0.0214(2)$ \\
\hline H9 & 0.752018 & 0.699503 & 0.256588 & $0.026^{*}$ \\
\hline $\mathrm{C} 10$ & 0.85375 & $0.76653(14)$ & $0.45357(13)$ & $0.0218(3)$ \\
\hline H10 & 0.899045 & 0.868220 & 0.442592 & $0.026^{*}$ \\
\hline $\mathrm{C} 11$ & $0.87453(17)$ & $0.71919(14)$ & $0.58064(13)$ & $0.0212(2)$ \\
\hline H11 & 0.930722 & 0.789112 & 0.656580 & $0.025^{*}$ \\
\hline C12 & $0.81286(16)$ & $0.56950(13)$ & $0.59597(12)$ & $0.0182(2)$ \\
\hline H12 & 0.827287 & 0.536650 & 0.682476 & $0.022 *$ \\
\hline
\end{tabular}


Atomic displacement parameters $\left(\AA^{2}\right)$

\begin{tabular}{lllllll}
\hline & $U^{11}$ & $U^{22}$ & $U^{33}$ & $U^{12}$ & $U^{13}$ & $U^{23}$ \\
\hline S1 & $0.01619(15)$ & $0.01550(15)$ & $0.01948(15)$ & $0.00207(10)$ & $0.00422(10)$ & $0.00084(10)$ \\
O1 & $0.0143(4)$ & $0.0183(4)$ & $0.0283(5)$ & $0.0016(3)$ & $0.0032(3)$ & $0.0041(3)$ \\
O2 & $0.0206(4)$ & $0.0148(4)$ & $0.0137(4)$ & $-0.0014(3)$ & $0.0016(3)$ & $0.0025(3)$ \\
O3 & $0.0282(5)$ & $0.0199(4)$ & $0.0162(4)$ & $-0.0027(3)$ & $-0.0008(3)$ & $-0.0003(3)$ \\
N1 & $0.0162(5)$ & $0.0147(5)$ & $0.0184(5)$ & $-0.0008(4)$ & $0.0025(4)$ & $0.0015(4)$ \\
N2 & $0.0149(4)$ & $0.0131(4)$ & $0.0141(4)$ & $0.0001(3)$ & $0.0018(3)$ & $0.0012(3)$ \\
C1 & $0.0162(5)$ & $0.0140(5)$ & $0.0144(5)$ & $0.0020(4)$ & $0.0001(4)$ & $0.0057(4)$ \\
C2 & $0.0170(5)$ & $0.0127(5)$ & $0.0203(5)$ & $-0.0024(4)$ & $0.0030(4)$ & $0.0017(4)$ \\
C3 & $0.0170(5)$ & $0.0157(5)$ & $0.0203(6)$ & $-0.0002(4)$ & $0.0005(4)$ & $-0.0021(4)$ \\
C4 & $0.0172(5)$ & $0.0146(5)$ & $0.0160(5)$ & $0.0027(4)$ & $0.0033(4)$ & $0.0019(4)$ \\
C5 & $0.0203(5)$ & $0.0136(5)$ & $0.0163(5)$ & $-0.0011(4)$ & $0.0030(4)$ & $0.0007(4)$ \\
C6 & $0.0139(5)$ & $0.0201(6)$ & $0.0147(5)$ & $0.0019(4)$ & $0.0024(4)$ & $0.0019(4)$ \\
C7 & $0.0134(5)$ & $0.0176(6)$ & $0.0169(5)$ & $0.0030(4)$ & $0.0029(4)$ & $0.0028(4)$ \\
C8 & $0.0178(5)$ & $0.0207(6)$ & $0.0160(5)$ & $0.0057(4)$ & $0.0015(4)$ & $0.0017(4)$ \\
C9 & $0.0234(6)$ & $0.0233(6)$ & $0.0206(6)$ & $0.0095(5)$ & $0.0048(5)$ & $0.0085(5)$ \\
C10 & $0.0209(6)$ & $0.0164(5)$ & $0.0301(6)$ & $0.0050(4)$ & $0.0058(5)$ & $0.0061(5)$ \\
C11 & $0.0202(6)$ & $0.0190(6)$ & $0.0231(6)$ & $0.0024(4)$ & $0.0001(5)$ & $-0.0007(5)$ \\
C12 & $0.0180(5)$ & $0.0204(6)$ & $0.0162(5)$ & $0.0027(4)$ & $0.0009(4)$ & $0.0028(4)$ \\
& & & & & &
\end{tabular}

Geometric parameters $\left(\AA,{ }^{\circ}\right)$

\begin{tabular}{llll}
\hline $\mathrm{S} 1-\mathrm{C} 1$ & $1.7082(11)$ & $\mathrm{C} 4-\mathrm{C} 5$ & $1.5141(15)$ \\
$\mathrm{O} 1-\mathrm{C} 3$ & $1.4259(14)$ & $\mathrm{C} 4-\mathrm{H} 4 \mathrm{~A}$ & 0.9900 \\
$\mathrm{O} 1-\mathrm{H} 1 \mathrm{O}$ & $0.840(9)$ & $\mathrm{C} 4-\mathrm{H} 4 \mathrm{~B}$ & 0.9900 \\
$\mathrm{O} 2-\mathrm{C} 6$ & $1.3462(14)$ & $\mathrm{C} 5-\mathrm{H} 5 \mathrm{~A}$ & 0.9900 \\
$\mathrm{O} 2-\mathrm{C} 5$ & $1.4460(13)$ & $\mathrm{C} 5-\mathrm{H} 5 \mathrm{~B}$ & 0.9900 \\
$\mathrm{O} 3-\mathrm{C} 6$ & $1.2121(14)$ & $\mathrm{C} 6-\mathrm{C} 7$ & $1.4847(16)$ \\
$\mathrm{N} 1-\mathrm{C} 1$ & $1.3454(15)$ & $\mathrm{C} 7-\mathrm{C} 12$ & $1.3941(16)$ \\
$\mathrm{N} 1-\mathrm{H} 1 \mathrm{~N}$ & $0.874(9)$ & $\mathrm{C} 7-\mathrm{C} 8$ & $1.3974(16)$ \\
$\mathrm{N} 1-\mathrm{H} 2 \mathrm{~N}$ & $0.876(9)$ & $\mathrm{C} 8-\mathrm{C} 9$ & $1.3859(17)$ \\
$\mathrm{N} 2-\mathrm{C} 1$ & $1.3424(15)$ & $\mathrm{C} 8-\mathrm{H} 8$ & 0.9500 \\
$\mathrm{~N} 2-\mathrm{C} 2$ & $1.4706(14)$ & $\mathrm{C} 9-\mathrm{C} 10$ & $1.3876(18)$ \\
$\mathrm{N} 2-\mathrm{C} 4$ & $1.4688(14)$ & $\mathrm{C} 9-\mathrm{H} 9$ & 0.9500 \\
$\mathrm{C} 2-\mathrm{C} 3$ & $1.5203(16)$ & $\mathrm{C} 10-\mathrm{C} 11$ & $1.3919(18)$ \\
$\mathrm{C} 2-\mathrm{H} 2 \mathrm{~A}$ & 0.9900 & $\mathrm{C} 10-\mathrm{H} 10$ & 0.9500 \\
$\mathrm{C} 2-\mathrm{H} 2 \mathrm{~B}$ & 0.9900 & $\mathrm{C} 11-\mathrm{C} 12$ & $1.3876(17)$ \\
$\mathrm{C} 3-\mathrm{H} 3 \mathrm{~A}$ & 0.9900 & $\mathrm{C} 11-\mathrm{H} 11$ & 0.9500 \\
$\mathrm{C} 3-\mathrm{H} 3 \mathrm{~B}$ & 0.9900 & $\mathrm{C} 12-\mathrm{H} 12$ & 107.8 \\
& & $\mathrm{H} 4 \mathrm{~A}-\mathrm{C} 4-\mathrm{H} 4 \mathrm{~B}$ & $108.15(9)$ \\
$\mathrm{C} 3-\mathrm{O} 1-\mathrm{H} 1 \mathrm{O}$ & $108.6(12)$ & $\mathrm{O} 2-\mathrm{C} 5-\mathrm{C} 4$ & 110.1 \\
$\mathrm{C} 6-\mathrm{O} 2-\mathrm{C} 5$ & $114.66(8)$ & $\mathrm{C} 4-\mathrm{C} 5-\mathrm{H} 5 \mathrm{H} 5 \mathrm{H}$ & 110.1 \\
$\mathrm{C} 1-\mathrm{N} 1-\mathrm{H} 1 \mathrm{~N}$ & $122.3(10)$ & $\mathrm{O} 2-\mathrm{C} 5-\mathrm{H} 5 \mathrm{~B}$ & 110.1 \\
$\mathrm{C} 1-\mathrm{N} 1-\mathrm{H} 2 \mathrm{~N}$ & $117.4(10)$ & & 110.1 \\
$\mathrm{H} 1 \mathrm{~N}-\mathrm{N} 1-\mathrm{H} 2 \mathrm{~N}$ & $117.2(14)$ & & \\
$\mathrm{C} 1-\mathrm{N} 2-\mathrm{C} 2$ & $121.80(9)$ & &
\end{tabular}




\begin{tabular}{|c|c|c|c|}
\hline $\mathrm{C} 1-\mathrm{N} 2-\mathrm{C} 4$ & $121.91(9)$ & $\mathrm{H} 5 \mathrm{~A}-\mathrm{C} 5-\mathrm{H} 5 \mathrm{~B}$ & 108.4 \\
\hline $\mathrm{C} 2-\mathrm{N} 2-\mathrm{C} 4$ & $116.29(9)$ & $\mathrm{O} 3-\mathrm{C} 6-\mathrm{O} 2$ & $122.83(10)$ \\
\hline $\mathrm{N} 2-\mathrm{C} 1-\mathrm{N} 1$ & $118.46(10)$ & $\mathrm{O} 3-\mathrm{C} 6-\mathrm{C} 7$ & $124.38(10)$ \\
\hline $\mathrm{N} 2-\mathrm{C} 1-\mathrm{S} 1$ & $121.95(8)$ & $\mathrm{O} 2-\mathrm{C} 6-\mathrm{C} 7$ & $112.78(9)$ \\
\hline $\mathrm{N} 1-\mathrm{C} 1-\mathrm{S} 1$ & $119.57(9)$ & $\mathrm{C} 12-\mathrm{C} 7-\mathrm{C} 8$ & $119.92(11)$ \\
\hline $\mathrm{N} 2-\mathrm{C} 2-\mathrm{C} 3$ & $112.00(9)$ & $\mathrm{C} 12-\mathrm{C} 7-\mathrm{C} 6$ & $122.18(10)$ \\
\hline $\mathrm{N} 2-\mathrm{C} 2-\mathrm{H} 2 \mathrm{~A}$ & 109.2 & $\mathrm{C} 8-\mathrm{C} 7-\mathrm{C} 6$ & $117.88(10)$ \\
\hline $\mathrm{C} 3-\mathrm{C} 2-\mathrm{H} 2 \mathrm{~A}$ & 109.2 & $\mathrm{C} 9-\mathrm{C} 8-\mathrm{C} 7$ & $119.84(11)$ \\
\hline $\mathrm{N} 2-\mathrm{C} 2-\mathrm{H} 2 \mathrm{~B}$ & 109.2 & $\mathrm{C} 9-\mathrm{C} 8-\mathrm{H} 8$ & 120.1 \\
\hline $\mathrm{C} 3-\mathrm{C} 2-\mathrm{H} 2 \mathrm{~B}$ & 109.2 & $\mathrm{C} 7-\mathrm{C} 8-\mathrm{H} 8$ & 120.1 \\
\hline $\mathrm{H} 2 \mathrm{~A}-\mathrm{C} 2-\mathrm{H} 2 \mathrm{~B}$ & 107.9 & $\mathrm{C} 8-\mathrm{C} 9-\mathrm{C} 10$ & $120.01(11)$ \\
\hline $\mathrm{O} 1-\mathrm{C} 3-\mathrm{C} 2$ & $112.86(9)$ & $\mathrm{C} 8-\mathrm{C} 9-\mathrm{H} 9$ & 120.0 \\
\hline $\mathrm{O} 1-\mathrm{C} 3-\mathrm{H} 3 \mathrm{~A}$ & 109.0 & $\mathrm{C} 10-\mathrm{C} 9-\mathrm{H} 9$ & 120.0 \\
\hline $\mathrm{C} 2-\mathrm{C} 3-\mathrm{H} 3 \mathrm{~A}$ & 109.0 & $\mathrm{C} 11-\mathrm{C} 10-\mathrm{C} 9$ & $120.41(11)$ \\
\hline $\mathrm{O} 1-\mathrm{C} 3-\mathrm{H} 3 \mathrm{~B}$ & 109.0 & $\mathrm{C} 11-\mathrm{C} 10-\mathrm{H} 10$ & 119.8 \\
\hline $\mathrm{C} 2-\mathrm{C} 3-\mathrm{H} 3 \mathrm{~B}$ & 109.0 & $\mathrm{C} 9-\mathrm{C} 10-\mathrm{H} 10$ & 119.8 \\
\hline $\mathrm{H} 3 \mathrm{~A}-\mathrm{C} 3-\mathrm{H} 3 \mathrm{~B}$ & 107.8 & $\mathrm{C} 12-\mathrm{C} 11-\mathrm{C} 10$ & $119.75(11)$ \\
\hline $\mathrm{N} 2-\mathrm{C} 4-\mathrm{C} 5$ & $112.81(9)$ & $\mathrm{C} 12-\mathrm{C} 11-\mathrm{H} 11$ & 120.1 \\
\hline $\mathrm{N} 2-\mathrm{C} 4-\mathrm{H} 4 \mathrm{~A}$ & 109.0 & $\mathrm{C} 10-\mathrm{C} 11-\mathrm{H} 11$ & 120.1 \\
\hline $\mathrm{C} 5-\mathrm{C} 4-\mathrm{H} 4 \mathrm{~A}$ & 109.0 & $\mathrm{C} 11-\mathrm{C} 12-\mathrm{C} 7$ & $120.01(11)$ \\
\hline $\mathrm{N} 2-\mathrm{C} 4-\mathrm{H} 4 \mathrm{~B}$ & 109.0 & $\mathrm{C} 11-\mathrm{C} 12-\mathrm{H} 12$ & 120.0 \\
\hline $\mathrm{C} 5-\mathrm{C} 4-\mathrm{H} 4 \mathrm{~B}$ & 109.0 & $\mathrm{C} 7-\mathrm{C} 12-\mathrm{H} 12$ & 120.0 \\
\hline $\mathrm{C} 2-\mathrm{N} 2-\mathrm{C} 1-\mathrm{N} 1$ & $178.51(9)$ & $\mathrm{O} 3-\mathrm{C} 6-\mathrm{C} 7-\mathrm{C} 12$ & $-177.03(11)$ \\
\hline $\mathrm{C} 4-\mathrm{N} 2-\mathrm{C} 1-\mathrm{N} 1$ & $-2.38(15)$ & $\mathrm{O} 2-\mathrm{C} 6-\mathrm{C} 7-\mathrm{C} 12$ & $1.55(15)$ \\
\hline $\mathrm{C} 2-\mathrm{N} 2-\mathrm{C} 1-\mathrm{S} 1$ & $0.22(15)$ & $\mathrm{O} 3-\mathrm{C} 6-\mathrm{C} 7-\mathrm{C} 8$ & $1.20(17)$ \\
\hline $\mathrm{C} 4-\mathrm{N} 2-\mathrm{C} 1-\mathrm{S} 1$ & $179.33(8)$ & $\mathrm{O} 2-\mathrm{C} 6-\mathrm{C} 7-\mathrm{C} 8$ & $179.78(9)$ \\
\hline $\mathrm{C} 1-\mathrm{N} 2-\mathrm{C} 2-\mathrm{C} 3$ & $82.67(13)$ & $\mathrm{C} 12-\mathrm{C} 7-\mathrm{C} 8-\mathrm{C} 9$ & $2.89(17)$ \\
\hline $\mathrm{C} 4-\mathrm{N} 2-\mathrm{C} 2-\mathrm{C} 3$ & $-96.49(11)$ & $\mathrm{C} 6-\mathrm{C} 7-\mathrm{C} 8-\mathrm{C} 9$ & $-175.38(10)$ \\
\hline $\mathrm{N} 2-\mathrm{C} 2-\mathrm{C} 3-\mathrm{O} 1$ & $49.39(13)$ & $\mathrm{C} 7-\mathrm{C} 8-\mathrm{C} 9-\mathrm{C} 10$ & $-1.46(17)$ \\
\hline $\mathrm{C} 1-\mathrm{N} 2-\mathrm{C} 4-\mathrm{C} 5$ & $80.00(13)$ & $\mathrm{C} 8-\mathrm{C} 9-\mathrm{C} 10-\mathrm{C} 11$ & $-0.84(18)$ \\
\hline $\mathrm{C} 2-\mathrm{N} 2-\mathrm{C} 4-\mathrm{C} 5$ & $-100.85(11)$ & $\mathrm{C} 9-\mathrm{C} 10-\mathrm{C} 11-\mathrm{C} 12$ & $1.71(18)$ \\
\hline $\mathrm{C} 6-\mathrm{O} 2-\mathrm{C} 5-\mathrm{C} 4$ & $172.96(9)$ & $\mathrm{C} 10-\mathrm{C} 11-\mathrm{C} 12-\mathrm{C} 7$ & $-0.26(18)$ \\
\hline $\mathrm{N} 2-\mathrm{C} 4-\mathrm{C} 5-\mathrm{O} 2$ & $59.09(12)$ & $\mathrm{C} 8-\mathrm{C} 7-\mathrm{C} 12-\mathrm{C} 11$ & $-2.03(17)$ \\
\hline $\mathrm{C} 5-\mathrm{O} 2-\mathrm{C} 6-\mathrm{O} 3$ & $-2.74(15)$ & $\mathrm{C} 6-\mathrm{C} 7-\mathrm{C} 12-\mathrm{C} 11$ & $176.17(10)$ \\
\hline $\mathrm{C} 5-\mathrm{O} 2-\mathrm{C} 6-\mathrm{C} 7$ & $178.64(9)$ & & \\
\hline
\end{tabular}

Hydrogen-bond geometry $\left(A,{ }^{\circ}\right)$

$\mathrm{Cg} 1$ is the centroid of the $(\mathrm{C} 7-\mathrm{C} 12)$ ring.

\begin{tabular}{lllll}
\hline$D-\mathrm{H} \cdots A$ & $D-\mathrm{H}$ & $\mathrm{H} \cdots A$ & $D \cdots A$ & $D-\mathrm{H} \cdots A$ \\
\hline $\mathrm{O} 1-\mathrm{H} 1 O \cdots \mathrm{S} 1^{\mathrm{i}}$ & $0.84(1)$ & $2.35(1)$ & $3.1746(9)$ & $169(2)$ \\
$\mathrm{N} 1-\mathrm{H} 2 N \cdots \mathrm{O} 1^{\text {ii }}$ & $0.88(1)$ & $2.04(1)$ & $2.8582(13)$ & $155(1)$ \\
$\mathrm{N} 1-\mathrm{H} 1 N \cdots \mathrm{O} 3^{\text {iii }}$ & $0.88(1)$ & $2.30(1)$ & $3.1218(13)$ & $158(1)$ \\
$\mathrm{C} 6-\mathrm{O} 3 \cdots C g 1^{\text {iv }}$ & $1.21(1)$ & $3.66(1)$ & $3.5026(12)$ & $73(1)$ \\
\hline
\end{tabular}

Symmetry codes: (i) $x+1, y, z$; (ii) $-x+1,-y,-z+2$; (iii) $-x+1,-y,-z+1$; (iv) $-x+1,-y+1,-z+1$. 